\title{
UJI IRITASI MATERIAL COBALT CHROMIUM SEBAGAI MATERIAL DASAR BONE PLATE UNTUK REKONSTRUKSI MANDIBULA
}

\author{
Dian Permata Sari, Eti Nurwening S., dan M.K. Herliansyah* \\ Universitas Gadjah Mada \\ Email drg.dianpermatasari@gmail.com dan mkherliansyah@gmail.com*
}

\begin{abstract}
The mandibular bone defect can cause speech disorder, mastication malfunction, and aesthetic problems. The application of plate for mandibular reconstruction can improve the function disorder. Plate material must be strong, resilient, able to adapt to the bone surface, and has good biocompatibility. Cobalt chromium is a cobalt base alloys are often used for implant materials. It has good mechanical properties, biocompatibility, and corrosion resistance. The aim of this study was to investigate the effect of local irritation and tissue response on material cobalt chromium. This study used three albino rabbits were injected by the material powder in polar and nonpolar solvents with intracutaneous injection method, then the treatments were observed on the first, second, and third days. Erythema and edema that occurs were scored based on grading system for intracutaneous (intradermal) reactions. Friedmann test showed no significant difference between treatment groups $(p>0.05)$. The results showed that erythema and edema arising from irritant reactions are still within normal limits. Irritation occurs due to the release of cobalt chromium ions which trigger hypersensitivity reactions and result in systemic immunity.
\end{abstract}

Keywords: Cobalt Chromium; Intracutaneous; Irritation; Mandibular Reconstruction.

\begin{abstract}
ABSTRAK
Kerusakan pada tulang mandibula menyebabkan gangguan fungsi bicara, mastikasi, dan estetika. Penggunaan plat untuk rekonstruksi mandibula dapat memperbaiki gangguan fungsi tersebut. Material plat harus kuat, ulet, dapat beradaptasi dengan permukaan tulang, dan memiliki biokompatibilitas yang baik. Cobalt chromium merupakan cobalt base alloy yang sering digunakan untuk material implant. Material ini memiliki sifat mekanis dan biokompatibilitas yang baik serta tahan korosi. Tujuan dari penelitian ini adalah untuk melihat efek iritasi dan respon lokal jaringan terhadap material cobalt chromium. Penelitian ini menggunakan 3 kelinci albino yang diinjeksi dengan serbuk material dalam pelarut polar dan nonpolar dengan metode injeksi intrakutan, kemudian dilakukan pengamatan pada hari pertama, kedua, dan ketiga. Eritema dan edema yang terjadi diberi skor berdasarkan tabel gradasi reaksi pemberian bahan uji secara intrakutan. Uji Friedmann menunjukkan tidak adanya perbedaan yang bermakna antar kelompok perlakuan $(\mathrm{p}>0,05)$. Kesimpulan penelitian ini adalah eritema dan edema sebagai reaksi iritasi masih dalam ambang normal. Iritasi yang terjadi merupakan efek pelepasan ion material cobalt chromium yang memicu terjadinya reaksi hipersensitivitas, yang dapat berakibat pada imunitas sistemik.
\end{abstract}

Kata Kunci: Cobalt Chromium; Intrakutan; Iritasi; Rekonstruksi Mandibular.

*) Corresponding Author 


\section{PENGANTAR}

Mandibula merupakan tulang yang berbentuk menyerupai tapal kuda dan menjadi perlekatan otot mastikasi yang berperan dalam fungsi bicara, mastikasi, dan estetika. Oleh karena itu apabila terjadi kerusakan pada tulang, mandibula akan mengganggu fungsifungsi tersebut (Okoje dkk, 2012). Kerusakan pada tulang mandibula dapat disebabkan oleh banyak hal, seperti kondisi patologis, trauma, infeksi, dan kelainan kongenital (Peterson dkk, 2003).

Prosedur rekonstruksi mandibula telah dikembangkan sejak 50 tahun yang lalu, dan masih terus dikembangkan untuk mendapatkan hasil rekonstruksi yang terbaik. Rekonstruksi mandibula dapat dilakukan dengan menggunakan bone graft sebagai filler material dan bone plate untuk proses fiksasinya. Shockley dkk, (1991) menyatakan bahwa penggunaan bone plate memiliki tujuan agar mandibula tetap dapat berfungsi dengan baik setelah proses rekonstruksi karena diharapkan bone plate dapat mengembalikan kontur mandibula seperti semula, selain itu penggunaan bone plate menjadi salah satu solusi untuk mengatasi keterbatasan donor tulang yang dapat digunakan untuk rekonstruksi.

Material yang digunakan untuk pembuatan plat harus memiliki kriteria kuat, ulet, dapat beradaptasi dengan permukaan tulang, dan memiliki biokompatibilitas yang baik (Prein, 1998). Plat berbahan dasar logam sering digunakan sebagai penyokong tulang maupun pengganti tulang yang digunakan untuk mempercepat pertumbuhan tulang dan membantu tulang berfungsi secara normal (Ionescu dkk, 2014). Sejumlah plat logam yang digunakan sebagai penyokong diantaranya titanium, stainless steel, dan cobalt based alloys (Park dan Bronzino, 2003).

Titanium digunakan sebagai implan untuk penggantian persendian, fiksasi tulang, implan gigi, alat pacu jantung, katup jantung, stent, dan beberapa komponen dalam sistem peredaran darah. Penggunaannya karena memiliki kekuatan yang baik dan stabilitas struktur kimia (Manivasagam dkk, 2010).
Stainless steel merupakan salah satu material yang dapat digunakan sebagai peralatan fiksasi karena memiliki sifat mekanis yang baik, tahan terhadap korosi, dan dalam produksinya membutuhkan biaya yang lebih murah dibandingkan logam lain. Jika dibandingkan dengan titanium, stainless steel memiliki kekakuan yang lebih, tetapi hal itu berakibat stainless steel kurang fleksibel dalam hal adaptasi permukaan tulang (Disegi dan Eschbach, 2000).

Cobalt base alloys merupakan biomaterial yang nonmagnetik, tahan lama dalam penggunaannya, dan tahan korosi. Material ini umum digunakan untuk implan gigi dan material pengganti lutut, bahu, serta panggul (Marti, 2000). Cobalt chromium merupakan cobalt base alloy yang memiliki stabilitas yang tinggi, kekuatan yang baik (Beumer dkk, 1996), selain itu merupakan alloy nonmagnetik yang memiliki ketahanan yang baik, tahan korosi, dan biokompatibilitas yang baik (Marti, 2000).

Bila dibandingkan dengan stainless steel, Titanium memiliki kemampuan adaptasi terhadap bermacam kontur tulang yang lebih baik. Selain itu infeksi yang akan timbul pada jaringan yang berinteraksi dengan Titanium lebih rendah bila dibandingakan dengan stainless steel (Deepak dan Manjula, 2011). Sedangkan cobalt chromium, memiliki kekuatan yang lebih baik, fleksibilitas yang lebih tinggi, dan ketahanan terhadap abrasi serta korosi yang lebih baik bila dibandingkan dengan stainless steel. Titanium memiliki modulus elastisitas yang lebih rendah dan paling mendekati dengan modulus elastisitas tulang, jika dibandingkan dengan material stainless steel dan alloy $\mathrm{CoCr}_{\mathrm{C}}$, tetapi pada penggunaan seperti persendian buatan dan plat tulang, seringkali rusak karena fatique (Manivasagam et al., 2010). Pada beberapa kasus disebutkan bahwa penggunaan stainless steel dan titanium berefek negatif pada tulang dan penyembuhannya. Plat akan dianggap tubuh sebagai benda asing, sehingga selama terjadi kontak antara tulang dan plat, terdapat kemungkinan terjadinya reaksi iritasi (Erdmann dkk, 2010). Cobalt chromium sudah biasa digunakan, tetapi mekanisme interaksi antara logam implan 
dengan jaringan di sekitarnya dan respon jaringan lokal terhadap material cobalt chromium belum sepenuhnya dipahami. Sehingga penelitian terkait hal tersebut masih terbuka lebar dan perlu dilakukan. Dalam penelitian ini akan dipelajari potensi terjadinya iritasi jaringan sebagai akibat interaksi antara material cobalt chromium dengan jaringan di sekitarnya.

Iritasi merupakan respon fisiologis tubuh terhadap adanya stimulus atau rangsang kimia (Vinardell dan Mitjans, 2008). Salah satu penyebab terjadinya iritasi adalah pelepasan ion dari material cobalt chromium. Reaksi pelepasan ion terkait dengan proses korosi (Geurtsen, 2002). Reaksi jaringan terhadap lepasnya ion bervariasi, mulai respon yang ringan hingga yang mengganggu homeostasis. Peningkatan pelepasan ion logam memperparah komplikasi dan berujung pada kegagalan implan (Virtanen dkk, 2008).

Uji iritasi merupakan salah satu uji biokompatibilitas. Uji biokompatibilitas dilakukan untuk melihat kemampuan suatu material untuk dapat berinteraksi, beradaptasi, dan memberikan respon terhadap jaringan. Uji iritasi yang dianjurkan untuk peralatan medis yang akan digunakan sebagai implan adalah uji iritasi intrakutan (intradermal). Uji ini dilakukan untuk melihat potensi material dalam menyebabkan iritasi melalui injeksi material secara intradermal.

Permasalahan yang timbul dalam penelitian ini adalah apakah cobalt chromium sebagai material dasar bone plate berpotensi menyebabkan iritasi pada jaringan? Penelitian ini bertujuan untuk menguji efek iritasi cobalt chromium sebagai material dasar bone plate dan menguji respon lokal jaringan terhadap material cobalt chromium.

\section{Metode}

Penelitian yang dilakukan adalah penelitian eksperimen kuasi dengan rancangan percobaan post test control design, menggunakan tiga ekor kelinci albino dengan ketentuan single strain, berat $\leq 2 \mathrm{~kg}$, dewasa, dan sehat. Kelinci dilakukan aklimatisasi selama 7 hari. Jumlah hewan coba ditentukan berdasarkan ISO 10993:10 tahun 2010, yaitu jumlah minimum yang dianjurkan dalam uji iritasi dengan metode intrakutan (intradermal). Penggunaan kelinci dalam penelitian, telah melalui tahapan persetujuan Komite Etik. Kelinci umum digunakan sebagai hewan coba dalam uji iritasi karena struktur dan susunan anatomi kelinci mirip dengan manusia (Samuelson, 2007), selain itu kelinci jenis albino memiliki daya tahan tubuh yang lebih tinggi, sehingga cukup kuat terhadap serangan penyakit dan dapat hidup dalam kondisi di bawah normal (Handayani, 2011) dan mempunyai respon immunologis dan patologis terhadap stress dan patogen yang mirip dengan manusia (Melillo, 2007).

Persiapan hewan coba dilakukan 4-18 jam sebelum perlakuan. Bulu pada punggung kelinci dicukur sekitar $10 \mathrm{~cm} \times 15 \mathrm{~cm}$ hingga kulit kelinci terlihat jelas. Menjelang perlakuan terhadap hewan coba, material cobalt chromium dalam sediaan serbuk disterilisasi dengan autoclave. Kemudian dengan perbandingan konsentrasi $0,2 \mathrm{gr} / \mathrm{mL}$, material cobalt chromium disiapkan pada masing-masing spuit. Spuit pertama berisi serbuk material cobalt chromium dalam air salin fisiologis, spuit kedua berisi serbuk material cobalt chromium dalam minyak sayur, spuit ketiga berisi air salin fisiologis, dan spuit keempat berisi minyak sayur.

Injeksi 0,2 mL pada tiap titik suntik sesuai area pada punggung kelinci (ISO 10993:10, 2010). Pada area A diinjeksi dengan serbuk material cobalt chromium dalam air salin. Area B diinjeksi dengan serbuk material cobalt chromium dalam minyak sayur. Area $C$ diinjeksi dengan air salin fisiologis. Sedangkan pada area D diinjeksi dengan minyak sayur. Posisi area injeksi tersebut ditunjukkan pada Gambar 1.

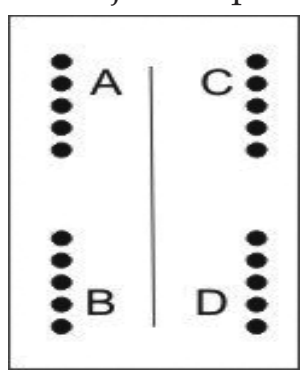

Gambar 1

Area dan Titik Suntik pada Punggung

Kelinci 
Pengamatan dilakukan selama tiga hari untuk melihat eritema dan edema yang terjadi, kemudian dilakukan penentuan skor dengan menggunakan tabel gradasi reaksi pemberian bahan uji secara intrakutan sesuai dengan standart ISO 10993:10 tahun 2010. Nilai eritema dan edema yang diperoleh, selanjutnya diambil reratanya sebagaimana ditampilkan pada Tabel 1. Untuk menghindari subjektivitas, proses pengamatan dan skoring dilakukan dibawah supervisi tenaga teknisi yang telah terlatih.

Tabel 1

Gradasi Reaksi Pemberian Bahan Uji Secara Intrakutan (ISO 10993:10, 2010)

\begin{tabular}{l|l}
\hline \multicolumn{1}{c|c}{ Reaksi } & \multirow{2}{*}{ Nilai } \\
\hline Pembentukan Eritema & 0 \\
\hline Tidak ada eritema & 1 \\
\hline Sangat sedikit eritema (nyaris tak terlihat) & 2 \\
\hline Eritema terlihat jelas & 3 \\
\hline Eritema sedang & 4 \\
\hline Eritema berat & \\
\hline Pembentukan Edema & 0 \\
\hline Tidak ada edema & 1 \\
\hline Sangat sedikit edema (nyaris tak terlihat) & 2 \\
\hline Edema terlihat jelas (disertai peninggian jaringan) & 3 \\
\hline Edema sedang (peninggian jaringan $\pm 1 m m)$ & 4 \\
\hline Nilai iritasi maksimum & 8 \\
\hline
\end{tabular}

\section{HASIL DAN PEMBAHASAN}

Hasil penelitian pada masing-masing kelompok perlakuan diberikan skor berdasarkan kriteria tabel gradasi reaksi pemberian bahan uji secara intrakutan (ISO 10993:10, 2010) seperti ditunjukkan pada Tabel 1. Pada hari pertama $(24 \pm 2$ jam setelah perlakuan) keseluruhan sampel tidak menunjukkan adanya eritema dan edema, yang ditandai dengan diberikannya nilai nol berdasarkan kriteria tabel. Jika dibandingkan keadaan sebelum perlakuan, sesudah perlakuan dan pengamatan hari pertama tidak terjadi perubahan warna dan dimensi pada kulit kelinci (Gambar 2a, b).

Pada hari kedua $(48 \pm 2$ jam setelah perlakuan) keseluruhan sampel pun tidak menunjukkan adanya eritema dan edema, sehingga diberikan pula nilai nol. Kulit kelinci tidak mengalami perubahan warna dan dimensi pada semua kelompok perlakuan (Gambar 2c). Akan tetapi, pada hari ketiga (72 \pm 2 jam setelah perlakuan) terdapat beberapa sampel yang menunjukkan adanya eritema yang sangat tipis (Gambar 2d). Eritema yang terjadi tidak diikuti terjadinya edema.

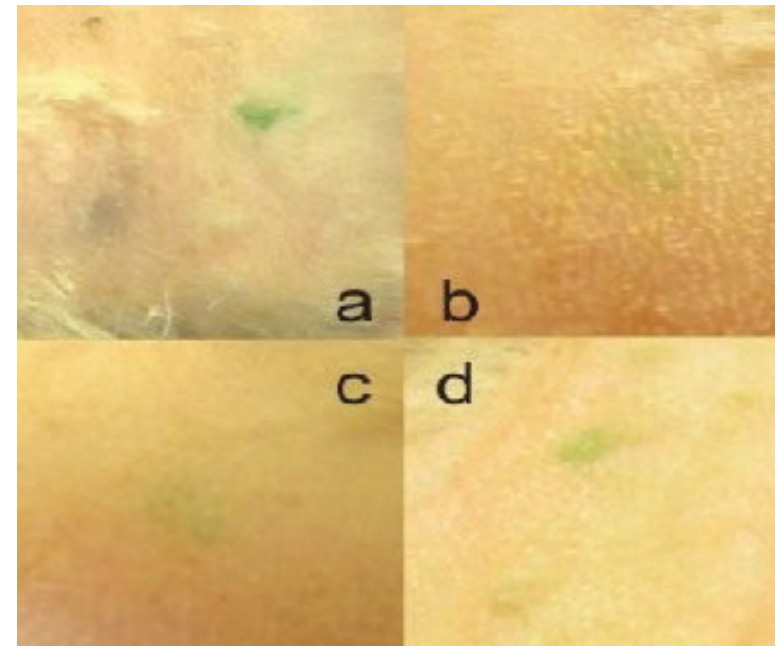

Gambar 2

Perbandingan perubahan warna kulit kelinci sesaat setelah perlakuan hingga pengamatan.

(a) kulit kelinci yang agak menggembung setelah diinjeksi dengan material coba; (b) pengamatan hari pertama tidak menunjukkan adanya eritema dan edema; (c) pengamatan hari kedua tidak menunjukkan adanya eritema dan edema; (d) pengamatan hari ketiga terjadi sedikit kemerahan yang sangat tipis, ditunjukkan dengan daerah yang dilingkari. 
Tabel 2

Rerata nilai eritema dan edema berdasarkan gradasi reaksi pemberian bahan uji secara intrakutan pada pengamatan hari pertama ( $24 \pm 2$ jam setelah perlakuan), hari kedua ( $48 \pm 2 \mathrm{jam}$ setelah perlakuan), dan hari ketiga (72 \pm jam setelah perlakuan)

\begin{tabular}{|c|c|c|c|c|c|c|c|c|c|c|c|c|c|c|c|c|c|c|}
\hline \multirow{2}{*}{ Hari } & \multirow{2}{*}{ Perlakuan } & \multicolumn{15}{|c|}{ Sampel } & \multirow{2}{*}{ Rerata } & \multirow{2}{*}{$\mathrm{P}^{*}$} \\
\hline & & 1 & 2 & 3 & 4 & 5 & 6 & 7 & 8 & 9 & 10 & 11 & 12 & 13 & 14 & 15 & & \\
\hline \multirow[t]{4}{*}{1} & A & 0 & 0 & 0 & 0 & 0 & 0 & 0 & 0 & 0 & 0 & 0 & 0 & 0 & 0 & 0 & 0 & \multirow[t]{12}{*}{0,261} \\
\hline & $B$ & 0 & 0 & 0 & 0 & 0 & 0 & 0 & 0 & 0 & 0 & 0 & 0 & 0 & 0 & 0 & 0 & \\
\hline & $\mathrm{C}$ & 0 & 0 & 0 & 0 & 0 & 0 & 0 & 0 & 0 & 0 & 0 & 0 & 0 & 0 & 0 & 0 & \\
\hline & $\mathrm{D}$ & 0 & 0 & 0 & 0 & 0 & 0 & 0 & 0 & 0 & 0 & 0 & 0 & 0 & 0 & 0 & 0 & \\
\hline \multirow[t]{4}{*}{2} & $\mathrm{~A}$ & 0 & 0 & 0 & 0 & 0 & 0 & 0 & 0 & 0 & 0 & 0 & 0 & 0 & 0 & 0 & 0 & \\
\hline & B & 0 & 0 & 0 & 0 & 0 & 0 & 0 & 0 & 0 & 0 & 0 & 0 & 0 & 0 & 0 & 0 & \\
\hline & $\mathrm{C}$ & 0 & 0 & 0 & 0 & 0 & 0 & 0 & 0 & 0 & 0 & 0 & 0 & 0 & 0 & 0 & 0 & \\
\hline & $\mathrm{D}$ & 0 & 0 & 0 & 0 & 0 & 0 & 0 & 0 & 0 & 0 & 0 & 0 & 0 & 0 & 0 & 0 & \\
\hline \multirow[t]{4}{*}{3} & $\mathrm{~A}$ & 0,5 & 0 & 0 & 0 & 0 & 0 & 0 & 0 & 0 & 0 & 0 & 0 & 0,5 & 0 & 0 & 0,067 & \\
\hline & $B$ & 0 & 0 & 0 & 0 & 0,5 & 0 & 0 & 0,5 & 0 & 0 & 0 & 0 & 0 & 0 & 0 & 0,067 & \\
\hline & $\mathrm{C}$ & 0 & 0 & 0 & 0 & 0 & 0 & 0 & 0 & 0 & 0 & 0 & 0 & 0 & 0 & 0 & 0 & \\
\hline & $\mathrm{D}$ & 0 & 0 & 0 & 0 & 0 & 0 & 0 & 0 & 0 & 0 & 0 & 0 & 0 & 0 & 0 & 0 & \\
\hline
\end{tabular}

Keterangan:

A : injeksi serbuk material cobalt chromium dalam salin

$\mathrm{B}$ : injeksi serbuk material cobalt chromium dalam minyak sayur

C : injeksi salin fisiologis

D : injeksi minyak sayur

* Uji Friedman

Tabel 2 menunjukkan nilai eritema dan edema selama pengamatan pada hari pertama, kedua, dan ketiga. Selain itu terdapat hasil analisis uji Friedman yang menunjukkan tidak adanya perbedaan yang bermakna antar kelompok perlakuan. Walaupun terjadi perubahan nilai eritema dan edema antara hari pertama dan kedua dengan hari ketiga, tetapi secara statistik tidak ada perbedaan bermakna.

Cobalt chromium dalam penelitian ini diinjeksikan ke dalam subkutan kelinci. Masuknya material ke dalam tubuh akan dianggap sebagai benda asing dan menimbulkan berbagai respon biologis. Respon jaringan meliputi perlukaan, reaksi inflamasi, penyembuhan luka, reaksi penolakan terhadap benda asing dan pembentukan jaringan fibrous (Anderson, 2001). Cobalt chromium yang digunakan sebagai material bone plate seharusnya dapat berkontak baik dengan jaringan dan tidak menimbulkan penolakan dari tubuh. Penolakan tubuh terhadap material asing merupakan tanda bahwa tubuh tidak kompatibel dengan material yang digunakan.

Berdasarkan hasil yang diperoleh, hari pertama dan kedua tidak terjadi reaksi iritasi.
Pada hari ketiga, beberapa sampel mengalami reaksi iritasi yang ditandai warna kemerahan yang terlihat samar. Kemerahan tersebut masuk dalam kategori skor 1 berdasarkan tabel gradasi reaksi pemberian bahan uji secara intrakutan. Skor 1 diberikan pada kondisi klinis kemerahan yang nyaris tidak terlihat (ISO 10993:10, 2010). Skor yang didapat saat penelitian kemudian dihitung reratanya. Rerata yang diperoleh adalah 0 dan 0,067 (Tabel 2). nilai tersebut kurang dari 1. Menurut ISO 10993:10 tahun 2010, angka tersebut masih dalam ambang normal, sehingga material dapat digunakan dalam tubuh.

Hasil uji Friedman menunjukkan antar kelompok perlakuan tidak memiliki perbedaan yang bermakna sehingga penggunaan serbuk material cobalt chromium yang dihantarkan dengan larutan polar dan nonpolar menghasilkan efek yang sama dengan kelompok kontrol yang hanya menggunakan larutan polar dan nonpolar tanpa serbuk material.

Kemerahan yang terjadi pada kulit kelinci (Gambar 2a, 2b, 2c, dan 2d) tersebut merupakan suatu kondisi yang disebut eritema. Respon eritema dan edema disebut 
iritasi yang merupakan respon fisiologis tubuh terhadap adanya stimulus atau rangsang kimia (Vinardell dan Mitjans, 2008).

Iritasi yang terjadi pada hari ketiga kemungkinan dapat disebabkan oleh beberapa hal, yang pertama teknik injeksi. Injeksi subkutan memerlukan teknik dan keahlian sehingga tidak terlalu sakit dan terhindar dari komplikasi salah satunya adalah iritasi. Pada teknik ini jarum dimasukkan 5,1 \pm mm dengan sudut $5^{\mathrm{O}}-15^{\mathrm{O}}$ (Hunter, 2008).

Pelepasan ion dari material cobalt chromium juga dapat menyebabkan terjadinya iritasi. Reaksi pelepasan ion terkait dengan proses korosi material (Geurtsen, 2002). Proses korosi pada sebuah material implan dipengaruhi oleh banyak faktor, termasuk dari material itu sendiri, seperti komposisi kimia, struktur mikro material, dan kondisi permukaan material. Selain itu $\mathrm{pH}$, suhu, dan kadar $\mathrm{O}_{2}$ dari lingkungan juga berperan dalam proses ini. Perubahan variabel-variabel tersebut berpengaruh pada pelepasan ion logam material. Reaksi jaringan terhadap lepasnya ion bervariasi, mulai respon yang ringan hingga yang mengganggu homeostasis. Peningkatan pelepasan ion logam memperparah komplikasi dan berujung pada kegagalan implan (Virtanen $\mathrm{dkk}, 2008)$.

Cobalt-based alloy dengan campuran chromium, cobalt chromium, akan membentuk lapisan oksida berupa chromium oxide ketika berinteraksi dengan oksigen. Hal ini akan menciptakan lapisan inert pada permukaan luar yang disebut dengan passive layer dengan ketebalan 1-4 nm yang akan memisahkan logam cobalt chromium dengan lingkungan sekitarnya. Dalam lapisan oksida tersebut terjadi reaksi transport ion yang dipengaruhi oleh komposisi kimia lapisan oksida, struktur, ketebalan, dan defek pada permukaan material implan (Virtanen dkk, 2008).

Ion logam yang terlepas akan bebas dan dapat menimbulkan toksisitas melalui mekanisme yang berpengaruh terhadap sistem enzimatik sel atau toksis secara langsung melalui infiltrasi membran. Ion logam dalam cobalt based alloy yang terlepas akan terikat pada protein sel dan menyebabkan terjadinya koagulasi. Infiltrasi membran biasanya terjadi pada ukuran nano-partikel, sehingga partikel dapat menembus membran sel dan merusak dari dalam sel (Okazakia dan Gotoh, 2008; Behl et al., 2013). Cobalt chromium dalam salin fisiologis akan melepaskan $30 \mu \mathrm{g} / \mathrm{cm}^{2}$ metal ke jaringan sekitar (Nicholson, 2002). Kadar ion logam $\mathrm{Fe}, \mathrm{Co}, \mathrm{Ni}, \mathrm{Cr}$ yang terlepas dan terlarut dari logam cobalt chromium sekitar 0,176; 1,41; 0,295; 0 ppm (Prasetyo, 2010). Penggunaan pelarut polar dan nonpolar dimaksudkan untuk melihat pengaruhnya terhadap pelepasan ion pada cobalt chromium.

Efek toksik dapat berupa toksisitas jaringan lokal, terjadinya inflamasi, kehilangan tulang, gangguan fungi ginjal, gangguan imun, reaksi hipersensitivitas, kerusakan kromosom, transformasi seluler, dan nekrosis jaringan (Jantzen dkk, 2013). Ambang batas toksisitas dari ion logam $\mathrm{Fe}, \mathrm{Co}, \mathrm{Ni}$, dan $\mathrm{Cr}$ berturut turut (dalam satuan ppm) adalah 59; 3,5; 1,1 dan 0,06 (Frazier dan Andrews, 1979).

Eritema yang terjadi juga merupakan efek dari reaksi hipersensitivitas akibat penggunaan cobalt chromium dalam tubuh. Berdasarkan Coombs dan Gell (1975; Baldo dan Pham, 2013) mengenai klasifikasi hipersensitivitas penggunaan obat, menunjukkan bahwa reaksi hipersensitivitas terbagi menjadi empat tipe reaksi, yaitu tipe I, II, III, dan IV (Tabel 3).

Tabel 3.

Klasifikasi Tipe Hipersensitivitas Berdasarkan Coombs Dan Gell (Baldo dan Pham, 2013)

\begin{tabular}{|c|c|c|c|c|}
\hline $\begin{array}{c}\text { Tipe } \\
\text { hipersensitivitas }\end{array}$ & $\begin{array}{l}\text { I } \\
\text { Immediate, } \\
\text { anafilaksis }\end{array}$ & $\begin{array}{c}\text { II } \\
\text { sitotoksisitas }\end{array}$ & $\begin{array}{c}\text { III } \\
\text { Imun Kompleks }\end{array}$ & $\begin{array}{l}\text { IV } \\
\text { Delayed, Cell Mediated, Tcell } \\
\text { Mediated }\end{array}$ \\
\hline Waktu & $\begin{array}{l}\text { Beberapa detik-30 } \\
\text { menit }\end{array}$ & $\begin{array}{l}\text { Beberapa jam-1 } \\
\text { hari }\end{array}$ & 3-10 jam & $24-72$ jam \\
\hline $\begin{array}{l}\text { Yang terlibat pada } \\
\text { sistem imun }\end{array}$ & $\operatorname{IgE}$ & IgG (dan IgM) & $\operatorname{IgG}($ dan IgM) & Th1, Th2, Th17, limfosit \\
\hline
\end{tabular}


Lanjutan Tabel 3

\begin{tabular}{|c|c|c|c|c|}
\hline $\begin{array}{c}\text { Tipe } \\
\text { hipersensitivitas }\end{array}$ & $\begin{array}{l}\text { I } \\
\text { Immediate, } \\
\text { anafilaksis }\end{array}$ & $\begin{array}{c}\text { II } \\
\text { sitotoksisitas }\end{array}$ & $\begin{array}{c}\text { III } \\
\text { Imun Kompleks }\end{array}$ & $\begin{array}{c}\text { IV } \\
\text { Delayed, Cell Mediated, Tcell } \\
\text { Mediated }\end{array}$ \\
\hline $\begin{array}{l}\text { Mekanisme } \\
\text { efektor }\end{array}$ & Aktivasi sel mast & Fagosit, sel NK & $\begin{array}{l}\text { Komplemen, } \\
\text { fagosit }\end{array}$ & $\begin{array}{l}\text { Aktivasi makrofag, limfosit, } \\
\text { aktivasi eosinofil }\end{array}$ \\
\hline $\begin{array}{l}\text { Respon } \\
\text { intradermal } \\
\text { terhadap antigen }\end{array}$ & $\begin{array}{l}\text { Kemerahan dan } \\
\text { pembengkakan }\end{array}$ & $\begin{array}{l}\text { Lisis dan } \\
\text { nekrosis }\end{array}$ & $\begin{array}{l}\text { Eritema dan } \\
\text { edema }\end{array}$ & $\begin{array}{l}\text { Eritema dan penebalan } \\
\text { pembuluh darah }\end{array}$ \\
\hline Histologi & $\begin{array}{l}\text { Terjadi } \\
\text { degranulasi sel } \\
\text { mast, ada infiltrasi } \\
\text { neutrofil }\end{array}$ & $\begin{array}{l}\text { Terdapat } \\
\text { komplemen, } \\
\text { neutrofil, } \\
\text { dan pada } \\
\text { imunoflouresens } \\
\text { menunjukkan } \\
\text { adanya antibodi }\end{array}$ & $\begin{array}{l}\text { Reaksi } \\
\text { inflamasi akut, } \\
\text { ada infiltrasi } \\
\text { neutrofil }\end{array}$ & $\begin{array}{l}\text { Inflamasi perivaskular, ada sel } \\
\text { mononuklear }\end{array}$ \\
\hline $\begin{array}{l}\text { Contoh penyakit } \\
\text { yang terjadi }\end{array}$ & $\begin{array}{l}\text { Eritema, urtikaria, } \\
\text { angioedema, } \\
\text { gangguan } \\
\text { pernapasan, } \\
\text { anafilaksis }\end{array}$ & $\begin{array}{l}\text { Anemia } \\
\text { hemolitik, } \\
\text { trombositopenia, } \\
\text { agranulositosis }\end{array}$ & Vasculatis & $\begin{array}{l}\text { Dermatitis kontak alergika, } \\
\text { psoriasis, maculopapular }\end{array}$ \\
\hline
\end{tabular}

Jika dibandingkan antara tipe-tipe hipersensitivitas pada Tabel 3, berdasarkan reaksi intradermalnya, kemungkinan reaksi eritema dan edema yang terjadi pada hewan coba termasuk dalam hipersensitivitas tipe I, III, dan IV karena pada ketiga tipe reaksi hipersensitivitas tersebut masing-masing menunjukkan gejala klinis eritema dan edema. Akan tetapi, jika ditinjau dari waktu terjadinya, eritema pada hewan coba termasuk dalam hipersensitivitas tipe IV. Untuk memastikan reaksi eritema dan edema yang terjadi diperlukan pengamatan terhadap antigen dan antibodi, serta pengamatan secara histologis untuk melihat sel yang terlibat. Akan tetapi, di dalam penelitian ini tidak dilakukan pengamatan tersebut.

\section{SIMPULAN}

Eritema dan edema yang terjadi sebagai reaksi iritasi masih dalam ambang normal. Iritasi yang terjadi merupakan efek pelepasan ion material cobalt chromium yang memicu terjadinya reaksi hipersensitivitas yang dapat berakibat pada imunitas sistemik

\section{DAFTAR PUSTAKA}

Anderson, J. M. 2001. "Biological response to materials." Annu. Rev. Matter. Res, 31(1):81-110.
Baldo, B.A., dan N.H. Pham. 2013. “Drug Allergy: Clinical Aspects, Diagnosis, Mechanisms." Structure-Activity Relationships, DOI 10.1007/978-1-46147261-2_2.

Behl, B., I. Papageorgiou, C. Browna, R. Hall, J.L. Tipper, J. Fisher, dan E. Ingham. 2013. "Biological Effects of Cobalt-Chromium Nanoparticles and Ions on Dural Fibroblasts and Dural Epithelial Cells." Biomaterials, 34: 3547-58.

Beumer, J., T. A. Curtis, dan D. N. Firtell. 1996. Maxillofacial Rehabilitation Prosthodontic and Surgical Considerations. C.V. Mosby Company.

Deepak, M. 2011. “Comparison of Titanium Bone Plates and Screws vs. Stainless Steel Bone Plates and Screws in the Management of Mandibular Fractures-A Long Term Clinical Study." International Journal of Clinical Dental Science.

Disegi, J. A. dan L. Eschbach. 2000. "Stainless steel in Bone Surgery." Injury, 2-6.

Erdmann, N., A. Bondarenko, M. HewickerTrautwein, N. Angrisani, J. Reifenrath, A. Lucas, dan A. Meyer-Linden- 
berg. 2010. "Evaluation of the soft tissue biocompatibility of $\mathrm{MgCa} 0.8$ and surgical steel 316L in vivo: a comparative study in rabbits." BioMedical Engineering Online, 9:63.

Geurtsen, W. (2002), “Biocompatibility of dental casting alloys." Critical Reviews in Oral Biology \& Medicine, 13(1):74-84.

Frazier ME, dan TK. Andrews. 1979. In vitro Clonal Growth Assay for Evaluating Toxicity of Metal Salts. Dalam Trace Metals in Health and Disease (ed. N. Karash). New York: Raven Press.

Handayani, F., 2011, “Kelinci Sebagai Tema Dalam Meningkatkan Karya Seni Grafis." Tugas Akhir. Surakarta: Universitas Sebelas Maret.

Hunter, J. 2008. "Subcutaneous Injection Techniques." Nursing Standard, 22(21).

International Organization for Standardization. 2010. International Standard 10993 Biological evaluation of medical devices - Part 10: Tests for irritation and skin sensitization. Switzerland.

Ionescu, R., M. Mardare, A. Dorobantu, S. Vermesan, E. Marinescu, R. Saban, I. Antoniac, D. N. Ciocan, dan M. Ceausu. 2014. "Correlation Between Materials, Design and Clinical Issues in the Case of Associated Use of Different Stainles Steels as Implan Materials." Key Engineering Materials, 583: 41-44.

Jantzen C, Jorgensen H L, Duus B R, Sporring S L, Lauritzen J B. 2013. “Chromium and cobalt ion concentrations in blood and serum following various types of metal-on-metal hip arthroplasties: a literature overview." Acta Orthop, 84 (3): 229-36.

Manivasagam, G., D. Dhinasekaran, dan A. Rajamanickam. 2010. "Biomedical Implans: Corrosion and its Prevention." Recent Patents on Corrosion Science, 2: 40-54.
Marti, A. 2000. "Cobalt-base alloys used in bone surgery." International Journal of the Care of the Injured, Elsevier, 31.

Melillo, A. 2007. "Rabbit Clinical Pathology" Journal of Exotic Pet Medicine, 16 (3): 135-145.

Nicholson, JW. 2002. The Chemistry of Medical and Dental Materials. Cambridge: Royal Society of Chemistry.

Okazakia, Y., dan E. Gotoh. 2008. "Metal Release from Stainless steel, Co$\mathrm{Cr}-\mathrm{Mo}-\mathrm{Ni}-\mathrm{Fe}$ and $\mathrm{Ni}-\mathrm{Ti}$ alloys in Vascular Implans." J Cor Sci. 50(12): 3429-38.

Okoje, V. N., O. S. Obimakinde, J. T. Arotiba, A. O. Fasola, S. O. Ogunlade, dan A.E. Obiechina. 2012. "Mandibular defect reconstruction with nonvascularized iliac crest bone graft." Nigerian Journal of Clinical Practice, 15.

Park, J. B., dan J. D. Bronzino. 2003. Metalis Biomaterials in Biomaterials: Principle and Applications, editors: Joon B Park and Joseph D Bronzino. New York: CRC Press.

Peterson, L. Minas, T. Brittberg, M, dan Lindahl, A. 2003. "Treatment of osteochondritis dissecans of the knee with autologous chondrocyte transplantation: results at two to ten years." J Bone Joint Surg Am, 85:17-24.

Prein, J., 1998, Manual of Internal Fixation in the Cranio-Facial Skeleton. Springer Science \& Business Media.

Prasetyo A. 2010. "Pengaruh Variasi Kandungan Silikon terhadap Korosi Paduan Kobalt (ASTM F 75) Hasil Metalurgi Serbuk dalam Larutan Artificial Blood Plasma dengan Teknik Polarisasi Potensiodinamik dan Teknik Exposure." Tesis, Jakarta: Universitas Indonesia.

Samuelson, D. A. 2007. Textbook of Veterinary Histology. St. Louis: Saunders Elsevier. 
Shockley, WW., MC. Weissler, dan HC. Pillsbury. 1991. Immediate mandibular replacement using reconstruction plates. Arch Otolaryngol Head Neck Surgery. 117(7):745-9.

Vinardell, M.P., dan M. Mitjans. 2008.

"Alternative Methods for Eye and
Skin Irritation Tests: An Overview." Journal of Pharmaceutical Science, 97 (1):46- 59 .

Virtanen, S., I. Milosev, E. Gomez-Barrena, R. Trebse, J. Salo, dan Y. T. Konttinen. 2008. "Special Modes of Corrossion Under Physiological and Simulated Physiological Conditions." Acta Biomaterial, 4(3):468-76. 